\title{
Žitarice i mlinski proizvodi kao dobar izvor magnezija u svakodnevnoj prehrani
}

1 Danijel Brkić

1,2 Jasna Bošnir

1 Andrea Jajetić

1 Ivana Prskalo

1 Jasenka Šabarić

1 Željka Kuharić

1 Željka Pavlek

3 Marijan Benić

2 Aleksandar Racz

1 Nastavni zavod za javni zdravstvo „Dr. Andrija Štampar”, Zagreb, Mirogojska 16

2 Zdravstveno veleučilište Zagreb, Zagreb, Mlinarska 16

3 Sanatio d.o.o. Zagreb, Bolnička cesta 34 c

\section{Sažetak}

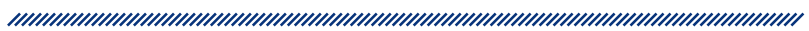

žitarice predstavljaju najrasprostranjeniju i najvažniju kulturu za prehranu ljudi. Važne su i kao sirovina u prehrambenoj industriji te čine osnovu piramide prehrane. Mlinski proizvodi također predstavljaju osnovne prehrambene proizvode. Glavni su mlinski proizvodi prekrupa, krupica i brašno. Magnezij je mineral koji je iznimno važan element u ljudskom organizmu. Zauzima četvrto mjesto po zastupljenosti kationa u organizmu te je drugi najčešći u stanicama. Ima važnu ulogu za katalitičku aktivnost više od 300 enzima u enzimatskim sustavima. Najvažniji je za pravilan rad srca te kao regulator fosfora i kalcija u kostima. Cilj je ovog rada utvrditi količinu magnezija u odabranim žitaricama i mlinskim proizvodima te prikazati zdravstvenu dobrobit magnezija. Tijekom analize sastava žitarica i mlinskih proizvoda analizirano je sveukupno 28 uzoraka. Od toga je bilo pet uzoraka kukuruza u zrnu, sedam uzoraka pšenice,
11 uzoraka pšeničnog brašna, brašno od integralne heljde bez glutena, zobena kaša, prosena kaša, kaša zobi, ječma i pira te kaša riže, kukuruza i heljde. Analiza je provedena na Nastavnom zavodu za javno zdravstvo „Dr. Andrija Štampar”. Magnezij je nakon digestije s nitratnom kiselinom i vodikovim peroksidom u mikrovalnoj pećnici određen induktivno spregnutom plazmom $\mathrm{s}$ masenom spektrometrijom (ICP-MS). Količine magnezija u žitaricama iznosile su od $81,92 \mathrm{mg} / 100 \mathrm{~g}$ do $145,21 \mathrm{mg} / 100 \mathrm{~g}$ za pšenicu te od 111,68 mg / $100 \mathrm{~g}$ do 145,21 mg / 100 g za kukuruz. Prosječna vrijednost magnezija iznosila je 105,81 mg / 100 g za uzorke pšenice te 133,72 mg / 100 g za uzorke kukuruza u zrnu. Količina magnezija utvrđena u pšeničnom brašnu kretala se $u$ rasponu od 23,17 mg / $100 \mathrm{~g}$ do 60,41 mg / 100 g, dok je srednja vrijednost magnezija iznosila $34,56 \mathrm{mg} / 100 \mathrm{~g}$. Količina magnezija u brašnu od integralne heljde bez glutena iznosila je 226,32 mg / 100 g. Utvrđena količina magnezija u zobenoj kaši, prosenoj kaši, kaši zobi, ječma i pira te kaši riže, kukuruza i heljde kretala se u rasponu od $76,77 \mathrm{mg} / 100 \mathrm{~g}$ do 153,61 mg / 100 g. Srednja vrijednost magnezija za uzorke kaše iznosila je 122,98 mg / 100 g.

Ključne riječi: mineral, dnevna potreba, mikroelement, magnezij

Datum primitka: 01.03.2020.

Datum prihvaćanja: 30.09.2020.

https://doi.org/10.24141/1/7/1/7

Adresa za dopisivanje:

Jasna Bošnir

A: Nastavni zavod za javni zdravstvo „, Dr. Andrija Štampar”,

Zagreb, Mirogojska 16

E-pošta: jasna.bosnir@stampar.hr

T: +385914678012 


\section{Uvod}

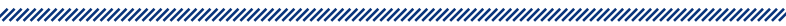

Žitarice predstavljaju jednu od najrasprostranjenijih i najvažnijih kulturnih biljaka za prehranu ljudi i životinja. Isto tako, važne su kao sirovina u prehrambenoj industriji te čine osnovu piramide prehrane. Žitarice imaju dugu povijest konzumiranja u ljudskoj prehrani. Pšenica i riža čine 50 \% ukupne svjetske proizvodnje žitarica. ${ }^{1}$ Predstavljaju osnovnu hranu u razvijenim zemljama, kao i u tranzicijskim zemljama. Važan su izvor ugljikohidrata, odnosno energije, proteina i vlakana te minerala i vitamina. Prema članku 2. Pravilnika o žitaricama i proizvodima o žitaricama, žitarice su „plodovi (zrnje) uzgajanih biljnih vrsta iz porodice trava (Poaceae) uključujući i heljdu, pogodni za neposrednu prehranu ljudi i preradu u mlinske, pekarske, tjesteničarske i slične proizvode". U žitarice ubrajamo: pšenicu, ječam, raž, zob, kukuruz, rižu, proso, sirak i pšenoraž (tritikale) te heljdu iz porodice dvornika (Polygonaceae) (članak 5.). ${ }^{2}$ Cjelovite žitarice, žitarice u prirodnom stanju, najbolji su, odnosno najzdraviji izbor prehrane kod ljudi. Postoje istraživanja koja dokazuju kako konzumacija cjelovitih žitarica ima ulogu u prevenciji kroničnih bolesti kao što su koronarne bolesti srca, dijabetesa i rak debelog crijeva. ${ }^{1}$ Upravo zbog takvih rezultata brojnih znanstvenih istraživanja cilj je potaknuti ljude na konzumiranje ove visokoenergetske i zdrave hrane. Velika je prednost cjelovitih žitarica i veliki izbor hrane čija su osnova koji je trenutačno dostupan na tržištu, kao i njihova jednostavna i brza priprema. Mlinski proizvodi također predstavljaju osnovne prehrambene proizvode od kojih je brašno najvažnije. Pšenica predstavlja osnovnu sirovinu mlinarske proizvodnje te je ujedno jedna od najvažnijih ratarskih kultura. ${ }^{3}$ Pravilnik o žitaricama i proizvodima od žitarica Ministarstva poljoprivrede RH mlinske proizvode definira kao proizvode dobivene od očišćenih, oljuštenih i pripremljenih žitarica postupcima usitnjavanja, odnosno mljevenja i njihova razvrstavanja. Prema ovom pravilniku, glavni su mlinski proizvodi prekrupa, krupica i brašno. Istraživanja u svrhu otkrivanja namirnica bogatim magnezijem od velike su važnosti. Organizam odrasle osobe sadrži $25 \mathrm{~g}$ magnezija, od čega se 50 do $60 \%$ nalazi u kostima. ${ }^{4}$ Magnezij zauzima četvrto mjesto po zastupljenosti kationa u organizmu, nakon kalcija, natrija i kalija, dok je u stanicama drugi najčešći, nakon kalcija. ${ }^{5,6}$ Ima važnu ulogu za katalitičku aktivnost više od 300 enzima u enzimskim sustavima kao što su: Krebsov ciklus, proces glikolize, put pentoze fosfata, glukoneogeneza, ciklus ureje i $\mathrm{dr}^{7}$ Znakovi nedostatka magnezija uključuju slabost, umor, gubitak apetita, grčeve u mišićima, mučninu, povraćanje, abnormalan srčani ritam, kao i promjene u ponašanju. ${ }^{8}$ Bez magnezija također bi bilo teško regulirati metaboličke i biokemijske reakcije u ljudskom organizmu. Uz sve zadaće, poput održavanja zdravlja živčanog i skeletnog sustava, važan je i za homeostazu drugih elektrolita, poput kalcija, natrija i kalija. ${ }^{9,10}$ Magnezij je esencijalni mikronutrijent za ljudski organizam. Prirodno je prisutan u raznim namirnicama, a sve se više dodaje u razne oblike dodataka prehrani i medicinske proizvode. Ključan je za metaboličke reakcije kao što su glikoliza, oksidativna fosforilacija, regulacija krvnog tlaka i glukoze, proizvodnja energije, sinteza nukleinskih kiselina i proteina, a važan je i za funkcije kao što su neuromuskularne funkcije, razvoj kostiju, imunitet i oksidativne funkcije. Održava ravnotežu elektrolita te homeostazu kalcija, natrija i kalija, što je iznimno važno za kontrakciju mišića, provođenje živčanih impulsa i normalni srčani ritam. ${ }^{11}$ Magnezij je moguće lako apsorbirati kroz crijeva. Bioraspoloživost magnezija uzetog oralnim putem iznosi 35 do $70 \%$, a ovisi o raznim faktorima (oblik magnezijeve soli - organska ili anorganska, vremenski raspon prijenosa magnezija iz crijeva u krv i brzina prijenosa u tkiva - magnezij je unutarstanični kation). ${ }^{9} 0$ važnosti magnezija za ljudski organizam govore i količine prisutne u organizmu. Organizam prosječnoga odraslog čovjeka sadrži oko $25 \mathrm{~g}$ magnezija. Od toga je 50 do $60 \%$ prisutno u kostima. Ostatak se nalazi u mekanom tkivu. Samo dio malo manji od $1 \%$ nalazi se u krvnom serumu, čiju količinu strogo reguliraju bubrezi. Normalne koncentracije magnezija u zdravoga odraslog čovjeka iznose 0,75 do $0,95 \mathrm{mmol} / \mathrm{l}$. Kod određenih bolesti bubrega koncentracija magnezija u krvnom serumu iznosi manje od $0,75 \mathrm{mmol} / \mathrm{l}$ i to se stanje naziva hipomagnezemija. Procjena ukupne količine magnezija u ljudskom organizmu iznimno je teška, baš zbog činjenice da se većina magnezija nalazi u kostima i stanicama. Najbrži je i najlakši način procjene mjerenje koncentracije u krvnom serumu, ali to nije odraz pravog stanja, iz navedenih razloga. Postoje još neke metode procjene stanja magnezija u organizmu, primjerice mjerenje koncentracije magnezija u eritrocitima, urinu ili slini. Može se mjeriti i koncentracija ioniziranog magnezija u krvi, plazmi i serumu, a nekad se provodi i test "tolerancije” na magnezij. Pri tom testu mjeri se koncentracija magnezija u urinu nakon dodatka poznate količine otopine magnezija. Najbolji je pristup mjerenju količine magnezija u organizmu s pomoću laboratorijskih testova i kliničke procjene. ${ }^{4}$ Trenutačno preporučene dnevne doze 
za unos magnezija i drugih mikronutrijenata u ljudski organizam definirao je Odbor za hranu i prehranu (Food and Nutrition Board - FNB) s Medicinskog instituta Nacionalnih akademija (Institute of Medicine of the National Academies) u SAD-u. ${ }^{12}$

Hipomagneziemija, stanje u kojem je kronična koncentracija magnezija u krvnom serumu niža od $0,75 \mathrm{mmol} / \mathrm{l}$, uzrokuje niz zdravstveno problematičnih stanja. Može biti posljedica dijareje, uzimanja antacida, uzimanja inhibitora protonske pumpe, diuretika, alkoholizma ili kroničnoga nedovoljnog unosa magnezija. Simptomi su uglavnom slabost i grčenje mišića te povećana iritativnost nervnog sustava (tremor, mišićni spazmi), a na početku su uglavnom slabi ili nisu prisutni. Zbog toga $\mathrm{i}$ nespecifičnih simptoma nedostatak magnezija u organizmu dosta je teško uočiti sve dok se razina u krvnom serumu ne spusti ispod $0,5 \mathrm{mmol} / \mathrm{l}$, kad simptomi postaju izraženi i jači. Hipomagnezemija u široj javnosti nije dobro poznata, ali je ozbiljna bolest koja može uzrokovati kronične bolesti ako se ne stavi pod kontrolu. Neke su od kroničnih bolesti koje uzrokuje: dijabetes 2 . tipa, bolesti kardiovaskularnog sustava, plućne bolesti, osteoporoza, depresija, razne upalne bolesti, migrene $\mathrm{i}$ neke vrste tumora. Problem kod detekcije ovog stanja leži u mjerenju stanja magnezija u organizmu. Osoba može čak imati normalnu razinu magnezija u krvnom serumu, dok, na primjer, u nekom tkivu ima nedovoljnu količinu. Zato se ova bolest uglavnom i opisuje kroničnim deficitom magnezija u mekim tkivima uz normalnu koncentraciju u krvnom serumu. ${ }^{9}$ Nedostatak magnezija dakle vodi do problema s razinom glukoze u krvi, dijabetesa 2. tipa, ateroskleroze, hipertenzije, bubrežnih bolesti i psiholoških poremećaja. ${ }^{11}$ Diabetes mellitus 1. i 2. tipa među vodećim je uzrocima nedostatka magnezija. Udio oboljelih od dijabetesa 2. tipa koji imaju i hipomagnezemiju varira od 13,5 do $47,7 \%$. Uzroci su nedovoljna konzumacija hrane koja je izvor magnezija, povećan gubitak magnezija putem bubrega i kronična dijareja uslijed neuropatije. Lijekovi poput inhibitora protonske pumpe mogu narušiti gastrointestinalnu apsorpciju magnezija. ${ }^{11}$

Nedavno su provedene studije koje pokazuju povezanost obolijevanja od dijabetesa 2. tipa i nedovoljne konzumacije magnezija. Došli su do zaključka da konzumacija hrane bogate magnezijem može pomoći kao prevencija za dijabetes 2 . tipa. Metaanaliza sedam studija od 1966. do 2007. istražila je tu povezanost, pri čemu je šest studija pokazalo izravnu korelaciju između rizika od dijabetesa 2. tipa i konzumacije magnezija, a u četiri studije ova je povezanost bila i statistički značajna. Na primjer, kod ispitanika koji su uzimali $100 \mathrm{mg}$ magnezija dnevno rizik od obolijevanja bio je iznimno velik. ${ }^{13}$ Ovim i mnogim drugim istraživanjima na ovu temu pokazano je da više količine konzumiranog magnezija smanjuju rizik od obolijevanja od dijabetesa 2. tipa i preddijabetičkog stanja. Budući da je dijabetes bolest koja je povezana s mikrovaskularnim i makrovaskularnim komplikacijama, ova je bolest velik problem javnog zdravstva u razvijenim zemljama. Komplikacije variraju od razine glukoze u krvi do bubrežnih bolesti, amputacija i demencije. Uvođenjem prehrane bogatije magnezijem ili odgovarajućih prehrambenih dodataka rizik od

\begin{tabular}{|c|c|c|c|c|}
\hline $\mathrm{DOB}$ & MUŠKARAC & ŽENA & TRUDNICA & DOJILJA \\
\hline $0-6$ mjeseci & $30 \mathrm{mg}^{*}$ & $30 \mathrm{mg}^{*}$ & & \\
\hline 7 - 12 mjeseci & $75 \mathrm{mg}^{\star}$ & $75 \mathrm{mg}^{*}$ & & \\
\hline $1-3$ godine & $80 \mathrm{mg}$ & $80 \mathrm{mg}$ & & \\
\hline $4-8$ godina & $130 \mathrm{mg}$ & $130 \mathrm{mg}$ & & \\
\hline $9-13$ godina & $240 \mathrm{mg}$ & $240 \mathrm{mg}$ & & \\
\hline $14-18$ godina & $410 \mathrm{mg}$ & $360 \mathrm{mg}$ & $400 \mathrm{mg}$ & $360 \mathrm{mg}$ \\
\hline 19 - 30 godina & $400 \mathrm{mg}$ & $310 \mathrm{mg}$ & $350 \mathrm{mg}$ & $310 \mathrm{mg}$ \\
\hline 31 - 50 godina & $420 \mathrm{mg}$ & $320 \mathrm{mg}$ & $360 \mathrm{mg}$ & $320 \mathrm{mg}$ \\
\hline $51+$ godina & $420 \mathrm{mg}$ & $320 \mathrm{mg}$ & & \\
\hline
\end{tabular}


ove bolesti i svih popratnih komplikacija tako se može znatno sniziti. ${ }^{11}$ Udruga za istraživanje magnezija (Association for Magnesium Research) ističe da bolesnici s dijabetesom 2. tipa koji suplementiraju magnezijem ili povećaju dnevni unos magnezija do RDA-a kroz hranu imaju čak četiri benefita. Unosom magnezija povećava im se inzulinska osjetljivost, poboljšava se regulacija stresa, smanjuje se antagonističko djelovanje na kalcij i dolazi do efekta stabilizacije endotela. ${ }^{11}$ Nedostatak magnezija sve se više povezuje i s kardiovaskularnim bolestima, od kojih se najviše ističe hipertenzija - stanje kronično povišenoga krvnog tlaka. Ova bolest nosi sa sobom veliki rizik od bolesti srca i srčanog udara. Svaka promjena u endogenom statusu magnezija vodi do promjena u kardiovaskularnom sustavu zbog promjena u tonusu žila i vrijednosti krvnoga tlaka. Već je pokazano da promjene u metabolizmu magnezija i kalcija utječu na početak hipertenzije. ${ }^{11}$ Provedena je i metaanaliza nasumičnih ispitivanja u kojima je mjeren utjecaj visoke suplementacije magnezijem na krvni tlak. Uočeno je smanjenje krvnog tlaka na razinu blizu normalne, ali razina smanjenja bila je isključivo povezana s dozom magnezija. Izmjereno je smanjenje sistoličkog tlaka za 4,3 $\mathrm{mm} \mathrm{Hg} \mathrm{i} \mathrm{2,3} \mathrm{mm} \mathrm{Hg} \mathrm{dijastoličkog} \mathrm{tlaka} \mathrm{za} \mathrm{svako} \mathrm{po-}$ većanje doze magnezija od $10 \mathrm{mmol}$ po danu. ${ }^{14}$ Razne druge studije potvrđuju pozitivan efekt suplementacije magnezijem kod oboljelih od hipertenzije u vidu smanjenja rizika od oboljenja od kardiovaskularnih bolesti povezanih s hipertenzijom. Najveće pozitivno djelovanje uočeno je kod oboljelih koji su pod stalnim uzimanjem diuretika ili koji nemaju zadovoljavajući dnevni unos magnezija. ${ }^{11}$

$\mathrm{U}$ zadnje vrijeme sve se više u široj javnosti podiže svijest o suplementiranju magnezijem za osobe koje putem hrane ne uzimaju dovoljne količine. Određeni nutricionisti čak preporučuju pojednostavljeno određivanje dnevnih potreba za magnezijem na temelju tjelesne težine (4 do $6 \mathrm{mg}$ po kilogramu tjelesne mase po danu). Valja napomenuti da se ovakve okvirne preporuke mogu uzeti za zdrave odrasle osobe koje nisu pretile. ${ }^{15}$ Kao prehrambeni suplement magnezij se može naći u sljedećim farmaceutskim oblicima: tabletama, kapsulama, efervetama i kao prah za izravno doziranje kroz usta. Što se tiče kemijskog sastava suplemenata prisutnih na hrvatskom tržištu, magnezij je prisutan u obliku anorganskih soli (magnezijev oksid i magnezijev klorid) te u obliku organskih soli (magnezijev citrat, magnezijev malat) i nekih drugih kelatiranih magnezijevih soli s aminokiselinama. Pretjerana konzumacija magnezija unesenog oralnim putem može uzrokovati gastrointestinalne tegobe poput dijareje, mučnine i povraćanja. Klinička slika pretjerane konzumacije magnezija intravenskim putem uključuje redom: žeđ, uspavanost, hipotenziju, slabost mišića, srčanu aritmiju, depresiju respiratornog sustava, komu i smrt. Kontinuirana konzumacija magnezija oralnim putem uzrokuje smetnje $u$ apsorpciji aminoglikozida i bifosfonata, blokira kalcijeve kanale, utječe na apsorpciju tetraciklina i mišićnih relaksanata. Posebnu pažnju kod doziranja magnezija oralnim putem treba obratiti kod bubrežnih bolesnika. ${ }^{16}$ Istraživanja diljem Europe i Sjeverne Amerike pokazala su da većina stanovništva unosi nedovoljno magnezija zbog tzv. zapadnjačkog načina prehrane, koji uključuje vrlo mnogo obrađene hrane. Razine unesenog magnezija tako su niske da se spuštaju do 30 do $50 \%$ RDA-a. U SAD-u se tijekom zadnjih 100 godina procjenjuje pad unosa magnezija s $500 \mathrm{mg}$ na dan na 175 do $225 \mathrm{mg}$ na dan. ${ }^{17}$ Spomenuti Odbor za hranu i prehranu iz SAD-a 1997. godine zato je povisio RDA za gotovo sve dobne skupine, na primjer: na $80 \mathrm{mg}$ na dan za djecu u dobi od jedne do tri godine i na $130 \mathrm{mg}$ na dan za djecu u dobi od četiri do osam godina. Magnezij se može naći u namirnicama biljnog i životinjskog porijekla. Najpoznatiji izvori svakako su cjelovite žitarice, razni orašasti plodovi i sjemenke, zeleno lisnato povrće poput špinata, mahune, mliječni proizvodi, meso, riba itd. Neki procesi obrade namirnica ipak snižavaju vrijednost magnezija, primjerice uklanjanje klice i sjemene lupine kod proizvodnje pšeničnog brašna, jer veći dio magnezija u sjemenki pšenice prisutan je u klici. Poznati je izvor magnezija i prirodna izvorska voda, čiji sastav i koncentracija magnezija u vodi varira ovisno o lokaciji izvora vode. ${ }^{11}$ Američka Agencija za hranu i lijekove (Food and Drug Administration - FDA) i American Association of Cereal Chemists International cjelovite žitarice definiraju kao netaknuto, samljeveno, napuklo ili ljušteno zrno s glavnim komponentama (sjemenom lupinom, škrobnim endospermom i klicom) prisutno u istim relativnim omjerima komponenti kao netaknuto zrno iste vrste. Dakle, sva zrna koja ulaze u proces obrade moraju imati iste udjele glavnih komponenti kao početno zrno da bi se mogla nazvati cjelovitom žitaricom. Definicija iz Pravilnika o žitaricama i proizvodima od žitarica Ministarstva poljoprivrede RH kaže da su žitarice su vrste iz porodice trava (Poaceae) u koje se ubrajaju: pšenica (uključujući krupnik/pir i khorasan), raž, ječam, zob, kukuruz, riža, proso, sirak i pšenoraž (tritikale) te heljda iz porodice dvornika (Polygonaceae). ${ }^{2}$ Sjemena lupina, dio sjemena žitarice, građena je od neprobavljivih netopivih ugljikohidrata (celuloza, hemiceluloza, arabinoksilan), dok su endosperm i klica građeni od 
viskoznih topivih vlakana, oligosaharida, lignina, rezistentnog škroba, vitamina, minerala, ulja, polifenola i drugih fitonutrijenata. Tijekom obrade cjelovitih žitarica u bijelo brašno dolazi do odvajanja klice i sjemene lupine. Preostali endosperm dalje se obrađuje u bijelo brašno. Usporedbom rafiniranih i cjelovitih žitarica vidi se da su cjelovite žitarice bogatije vlaknima (za oko $80 \%$ više), vitaminima, mineralima i fitonutrijentima. ${ }^{18}$ O važnosti žitarica za ljudsku prehranu govori podatak da makronutrijenti konzumirani iz žitarica tijekom dana prosječno zadovoljavaju $50 \%$ dnevnih potreba za ugljikohidratima, trećinu dnevnih potreba za proteinima i 50 do $60 \%$ dnevnih potreba za vitaminima B skupine. ${ }^{10}$

Razne agencije i društva u Americi zadnjih dvadesetak godina provode edukacije i daju preporuke za uzimanje barem polovine žitarica u obliku cjelovitih žitarica. ${ }^{18}$ Tim preporukama u zadnje se vrijeme pridružuju i hrvatski mediji i razni nutricionisti.

Prve zabilježene žitarice koje su ljudi upotrebljavali bile su iz porodice Poaceae, od kojih je ječam jedna od prvih uzgajanih kultura, još 5000 godina prije nove ere u Egiptu i Babilonu. Danas sveprisutna pšenica počela se uzgajati u vrijeme neolitika na području Euroazije. ${ }^{10}$

Neke su od cjelovitih žitarica pšenica, zob, ječam, smeđa riža, kukuruz, raž, proso i kineska šećerna trska.

Najpoznatiji su proizvodi od ovih žitarica brašno i kruh od cjelovitih žitarica (pšenica, kukuruz), tjestenina od cjelovitih žitarica, tortilja od cjelovitih žitarica, zobena kaša i zobene pahuljice, kokice, raženi kruh, gotove grickalice (krekeri i pločice od cjelovitih žitarica) te razni kolači od cjelovitih žitarica. ${ }^{18}$ Za neke od predstavnika cjelovitih žitarica u tablici 2 prikazan je makronutritivni sastav.

Pšenica se počela uzgajati u vrijeme neolitika na području Euroazije. ${ }^{10}$ Razni zapisi i nalazi govore da je pšenica kao žitarica poznata barem 10000 godina. Otkrićem Amerike uzgoj pšenice jako se povećao širenjem na novi kontinent. ${ }^{19}$ Godine 1996. 32,4 \% ukupnih uzgajanih kultura otpalo je na pšenicu. Glavni su proizvođači pšenice SAD, Kanada, Argentina, Australija i Francuska. ${ }^{10}$ Pšenica je važna za niz industrija: mlinarsku industriju i pekarske proizvode, farmaceutsku industriju, industriju dizajna interijera i pivarsku industriju. ${ }^{19}$ Dobro se prilagođava klimi i promjeni tla. Danas u svijetu postoji mnogo vrsta i kultivara pšenice. Mnogobrojne vrste za posljedicu imaju i mnogobrojne proizvode - zrna s različitim sastavom. Svaka biljka pšenice sastoji se od korijena, stabljike, lista, cvijeta i ploda. Pšenica od klice do konačnog ploda prolazi sljedeće faze: bubrenje i klijanje, nicanje, ukorjenjivanje, busanje, vlatanje, klasanje, cvjetanje i oplodnja, formiranje, nalijevanje te sazrijevanje zrna. Plod je na biljci u obliku klasa, koji obično sadrži 30 do 40 zrna. ${ }^{19}$ Najveći dio vitamina i minerala u zrnu pšenice nalazi se klici i sjemenoj lupini - točnije, u aleuronskom sloju. Također, nešto minerala nalazi se $u$ škrobnom endospermu. ${ }^{10}$ Zbog velikog udjela ugljikohidrata i proteina prigodna je za svakodnevnu konzumaciju jer daje dovoljno energije iz dobrih nutrijenata. ${ }^{20}$

Uzgajanje ječma imalo je veliki utjecaj na tropske i suptropske predjele Azije i Afrike. ${ }^{10}$ Glavni su proizvođači Indija i Niger, gdje je ječam i iznimno važna žitarica za prehranu ljudi i životinja. Ovo je žitarica s malim zrnima i mnogo različitih vrsta. lako u Europi i Americi nije više popularan kao prije, u zemljama Azije i Afrike ječam je važna namirnica za pripremu tradicionalnih jela i pića. Ječam ima veliku količinu vlakana (tablica 2), što povoljno djeluje u prevenciji raka i za regulaciju normalne probave. Provedena su brojna znanstvena istraživanja koja potvrđuju zdravstvene benefite konzumacije ječma. Jedini je problem kod ove žitarice što se prije konzumacije mora pravilno obraditi da se poboljšaju nutritivna i osjetilna svojstva. To se provodi fermentacijom, rezanjem u pahuljice, prženjem, kuhanjem i sličnim procesima. Do problema dolazi zbog toga što tijekom tih procesa nije jednostavno spriječiti i neželjene reakcije i promjene. ${ }^{21}$

\begin{tabular}{|c|c|c|c|c|c|}
\hline \multicolumn{6}{|c|}{ Tablica 2. Makronutrijenti pojedinih cjelovitih žitarica na 100 grama žitarice } \\
\hline ŽITARICA & $\begin{array}{c}\text { ENERGIJA } \\
\text { kJ / 100 g }\end{array}$ & UGLJIKOHIDRATI & OD TOGA VLAKNA & PROTEINI & MASTI \\
\hline Pšenica & 1421 & 75,4 & 12,7 & 10,7 & 1,99 \\
\hline Zob & 1626 & 66,3 & 10,6 & 16,89 & 6,9 \\
\hline Ječam & 1480 & 73,5 & 17,3 & 12,48 & 2,3 \\
\hline Smeđa riža dugog zrna & 1547 & 77,2 & 3,5 & 7,9 & 2,9 \\
\hline Izvor: S. S. Jonnalagdda, 2011.; A. S. M. Saleh, 2013.
\end{tabular}


Raži i zob žitarice su takozvane sekundarne kulture, prisutne uglavnom na sjevernoj hemisferi, čak i u klimi nepovoljnoj za uzgoj ostalih žitarica. Uzgajaju se zadnjih 1000 godina. Zbog dobre otpornosti na oštru klimu, raž i zob u sjevernim su predjelima gotovo istisnuli uzgoj pšenice i ječma. ${ }^{10}$ Proizvodi s većim udjelom raži u svojem sastavu u istraživanjima su pokazali povećanje sitosti i smanjenje lučenja inzulina nakon obroka u usporedbi s konzumacijom proizvoda s rafiniranim pšeničnim bijelim brašnom. Zato može pomoći u prevenciji dijabetesa 2. tipa i pretilosti. ${ }^{22}$

Zob se sve više upotrebljava u proizvodnji dječje hrane zbog nutritivnog sastava, dobrog okusa, dobre stabilnosti i otpornosti na kvarenje, slabe prisutnosti alergena i niske cijene. Uglavnom se na policama trgovačkih lanaca nalazi u obliku zobene kaše, zobenih pahuljica, zobenog brašna, zobenih keksa i kao dio pahuljica müsli. Kod zobi je važno istaknuti velik udio vlakana (tablica 2), koja povoljno djeluju na prevenciju dijabetesa, pretilosti i nekih vrsta raka. Svjetska zdravstvena organizacija (World Health Organization - WHO) predlaže dnevni unos od barem 25 grama vlakana. Prosječna konzumacija vlakana pak u Europi iznosi 15 do $20 \mathrm{~g}$ i u SAD-u 12 do $18 \mathrm{~g}$, dok je u Africi 40 do $60 \mathrm{~g}$. Kod zobenih je vlakana specifično što su dio tih vlakana $\otimes$-glukani (2,7 do 3,5 g po $100 \mathrm{~g}$ zobi). Za $\otimes$-glukane, pogotovo $\bigotimes$-1,4-glukane, znanstveno je dokazano da povoljno djeluju na imunitet ljudi. ${ }^{23}$

Riža i kukuruz kao žitarice počele su se uzgajati prije 5000 godina, najprije u tropskoj jugoistočnoj Aziji, a zatim i u Srednjoj i Južnoj Americi. ${ }^{10}$ Najveća proizvodnja riže 2006. godine zabilježena je u Aziji. ${ }^{10}$ Riža se većinom konzumira u obliku bijele riže, iako smeđa riža (cjelovito zrno) postaje sve popularnija u zapadnjačkim zemljama zbog svojih benefita za ljudsko zdravlje. Neki su od proizvoda od riže rižino brašno, rižin sirup, rižino mlijeko, rižine pahuljice i slično. lako sadrži malo vlakana, a mnogo ugljikohidrata (amilozu iz škroba - koja se često nakon hlađenja termički obrađenog jela naziva rezistentnim škrobom), spada pod vlakna. Cjelovito zrno riže ipak je najzdraviji izbor, s obzirom na to da sadrži razne vitamine i minerale, uključujući magnezij. ${ }^{24}$ Povećana konzumacija cjelovitog zrna smeđe riže povezana je s prevencijom bolesti kardiovaskularnog sustava, ${ }^{25}$ regulacijom tjelesne težine i regulacijom kolesterola. ${ }^{24}$ Ipak, s rižom treba biti oprezan jer postoje istraživanja koja ukazuju na povećani rizik od dijabetesa 2. tipa. Unatoč sadržaju magnezija koji djeluje preventivno na ovu bolest, vrlo visok glikemijski indeks ipak ima jači učinak te stoga povećava rizik. ${ }^{24}$
Kukuruz je dobar primjer velikih misterija evolucije biljke i pripitomljavanja. Naime, divlja meksička trava Zea mays ssp. parviglumis genski je slična kukuruzu, ali postoje ipak znatne razlike u strukturi kukuruza koje onemogućuju razvoj modela koji bi dobro opisao evolucijske korake u razvoju kukuruza. ${ }^{26}$ To nije spriječilo čovječanstvo da ovu žitaricu pretvori u jednu od najraširenijih na svijetu. Upotrebljava se za prehranu ljudi i životinja, biogorivo te kao materijal u raznim industrijama. Danas je veliki udio kukuruza genetički modificiran kako bi se dobila tolerancija na sušna razdoblja te rezistencija na poznati herbicid glifosat i na određene kukce. Proizvodi od kukuruza uglavnom su kukuruzni kruh, palenta, kukuruzno brašno, tortilje, rižini krekeri, kokice, kukuruzni sirup i slično proizvodi. ${ }^{27}$

Uz klasične žitarice postoje i pseudožitarice. Predstavnici su ove skupine amarant, heljda i kvinoja. ${ }^{10}$ Pseudožitarice su biljke koje ne pripadaju porodici trava (Poaceae), ali im je nutritivni sastav sličan i na slične se načine upotrebljavaju. Sjemenke pseudožitarica, dakle, mogu se mljeti i obrađivati kao i sjemenke pravih žitarica. ${ }^{28}$ Uzgoj pseudožitarice kvinoje poznat je više od 5000 godina, a prvi zapisi o kvinoji potječu od drevnog društva Inka. Sa $64 \mathrm{~g}$ ugljikohidrata, $14 \mathrm{~g}$ proteina i $6 \mathrm{~g}$ masti (sirove) pružala im je dobar izvor energije. Prehrambena vlakna $(7 \mathrm{~g})^{19}$ upotpunila su ovaj sastav uravnotežujući probavu. Dobar je izvor raznih vitamina, minerala i antioksidansa, koji su Inkama davali snagu. Prirodno na sebi sadrži saponine, spojeve koji služe za odbijanje kukaca. Tako je ova biljka odlična hrana koja se sama brine za sebe. Uspijeva u toplim i vlažnim klimama. ${ }^{28}$ Također, povoljno djeluje na prevenciju bubrežnih kamenaca i bolesti krvožilnog sustava. Prije konzumacije potrebno ju je isprati pod hladnom vodom da se uklone saponini. Kuha se samo 15 minuta, ugodnog je orašastog okusa i od nje se mogu pripremiti razna slana i slatka jela. Najpopularnije su salate, koje i pomažu rastu popularnosti kvinoje. ${ }^{28}$

Heljda kao druga važna pseudožitarica konzumira se većinom u obliku sjemenki. Sjemenke heljde od davnina se upotrebljavaju za prehranu ljudi, pogotovo na području Balkana. Zato je danas i poznata kao hrana naših baka. Ova biljka lako uspijeva i na siromašnom tlu, a smanjuje količinu korova na polju, zbog čega ju je bilo lako uzgajati u Europi, Aziji i Americi. Uzgoj heljde dosta je varirao kroz prošlost. Ipak, zadnjih godina vidljiv je povratak heljde na domaće jelovnike, jer se sve više naglašavaju pozitivne posljedice njezine konzumacije. ${ }^{29}$ Heljda je dobar izvor rezistentnog škroba, vrste vlakana, i zbog toga ima nizak glikemijski indeks. Odli- 
čan je izvor i proteina (13 g), vlakana (10 g), polifenola, vitamina i minerala. Zanimljivo je što u određenim količinama pokazuje fotosenzibilizirajuće djelovanje zbog prisustva fotokemikalija. To može dobro doći u ciljanom liječenju određenih tkiva, dok može imati i negativan utjecaj kod neopreznih osoba. ${ }^{29}$ Ipak, pruža mnogo zdravstvenih benefita kao što su: prevencija dijabetesa, neuroprotektivno i protuupalno djelovanje te regulacija razine kolesterola i krvnog tlaka. ${ }^{30} \mathrm{U}$ tablici 3 navedene su prisutne količine magnezija u pojedinim žitaricama, iz čega je vidljivo da zob i pšenica sadrže najviše magnezija u svojem sastavu.

Pravilnik o žitaricama i proizvodima od žitarica Ministarstva poljoprivrede $\mathrm{RH}$ mlinske proizvode definira kao proizvode dobivene od očišćenih, oljuštenih i pripremljenih žitarica postupcima usitnjavanja, odnosno mljevenja i njihova razvrstavanja. Prema ovom pravilniku, glavni su mlinski proizvodi prekrupa, krupica i brašno. Također propisuje da mlinski proizvodi ne smiju sadržavati više od $15 \%$ vode, a boja, miris i okus moraju odgovarati vrsti žitarice. Ne smiju sadržavati više od $0,5 \%$ nečistoće biljnog podrijetla i ne smiju sadržavati više od 0,05 \% pijeska, uz iznimku heljdina brašna, koje ne smije sadržavati više od $0,2 \%$ pijeska. $^{2}$

Mlinski proizvodi mogu biti pripravljeni od svih vrsta žitarica, ali će im se zato svojstva znatno razlikovati, s obzirom na to da se i žitaricama relativno razlikuje sastav. Najpopularniji su proizvodi od pšenice, dok se sve više počinju upotrebljavati i kukuruz te raž.

U skupinu mlinskih proizvoda od pšenice uključeni su: brašno, krupica (griz), prekrupa, klice za ljudsku prehranu, mekinje za ljudsku prehranu, namjensko brašno, sterilizirano brašno, sterilizirana krupica i namjenska krupica te brašno i krupica za brzo pripremanje jela. Namjensko brašno i krupica mlinski su proizvodi koji posjeduju posebne karakteristike. Razlikuju se od klasičnih brašna i krupica po tome što su prilagođeni određenim zahtjevima s obzirom na vrstu gotovih proizvoda koji će se od njih pripremati. ${ }^{31} \mathrm{Na}$ tržištu postoji više od 15 vrsta mlinskih proizvoda od pšenice, uključujući razne tipove bijelog i crnog brašna te prekrupe. Najpoznatija su četiri tipa krupice i brašna (pšenica): krupica (griz) tipa 400, brašno tipa 500, tipa 850 i tipa 1100, namjensko brašno i namjenska krupica.

Ječam i zob mogu se obrađivati na sličan način pa stoga na tržištu postoje slični oblici proizvoda od ovih dviju žitarica. Uglavnom je riječ o brašnu i pahuljicama cjelovitog zrna.

Raž, bilo da se proizvodi proizvode od čiste raži bilo od mješavine raži i pšenice, dolazi u obliku: ražene prekrupe, raženog brašna i mekinja. Tipovi su prekrupe i brašna od raži: brašno tipa 750, brašno tipa 950 te brašno tipa 1250 .

Kukuruz je nešto zahvalniji za obradu od raži pa se od njega mogu dobiti slični mlinski proizvodi kao od pšenice. Uglavnom su to: brašno, prekrupa, mekinje, klice i krupica, a sve je veća potražnja i za prekupom, krupicom i brašnom za brzo pripremanje jela, s obzirom na to da užurbani način života sve više traži instant-jela. ${ }^{31}$

Važno je naglasiti da svi ovi mlinarski proizvodi mogu biti napravljeni od cjelovitog zrna žitarice ili od zrna kojem su uklonjeni klica i sjemena lupina. To obvezno mora biti naglašeno na deklaraciji, da kupac bude obaviješten o proizvodu koji kupuje. Svi čisti mlinski proizvodi i mlinske mješavine za pekarske proizvode proizvedeni u Hrvatskoj i uvezeni u Hrvatsku moraju zadovoljavati određene standarde kvalitete postavljene u Pravilniku o žitaricama i proizvodima od žitarica Ministarstva poljoprivrede RH. Tamo su definirani i nazivi proizvoda napravljenih od određenih mlinskih proizvoda uz popratnu regulaciju sastava. ${ }^{2}$

\begin{tabular}{|c|c|c|c|}
\hline \multicolumn{3}{|c|}{ Tablica 3. Količina magnezija u pojedinim žitaricama, na 100 grama sirove žitarice } \\
\hline ŽITARICA & Self nutrition data, 2018. & USDA 2018 & NutritionValue. Org, 2018. \\
\hline Pšenica & 144 & 93 & 144 \\
\hline Ječam & 76 & 79 & 79 \\
\hline Raž & 121 & 110 & 110 \\
\hline Zob & 177 & 235 & 177 \\
\hline Smeđa riža & 143 & 112 & 116 \\
\hline Kukuruz & 137 & 127 & 127 \\
\hline Kvinoja & 197 & 197 & 197 \\
\hline Heljda & 231 & 231 & 231 \\
\hline
\end{tabular}




\begin{tabular}{|c|c|}
$\begin{array}{c}\text { Tablica 4. Količine magnezija u mlinarskim } \\
\text { proizvodima određenih žitarica u sirovom } \\
\text { stanju }\end{array}$ \\
\hline MLINSKI PROIZVOD & $\begin{array}{c}\text { KOLIČINA MAGNEZIJA } \\
\text { (mg / } 100 \text { g) }\end{array}$ \\
\hline Bijelo pšenično brašno & 20 \\
\hline $\begin{array}{c}\text { Pšenično brašno od } \\
\text { cjelovitog zrna }\end{array}$ & 120 \\
\hline $\begin{array}{c}\text { Instantna bijela riža, } \\
\text { oljuštena }\end{array}$ & 32 \\
\hline Smeđa riža cjelovitog zrna & 110 \\
\hline Brašno od smeđe riže & 92 \\
\hline Instantna zobena kaša & 110 \\
\hline Izvor: McKevith, 2004. & \\
\hline
\end{tabular}

\begin{tabular}{|c|c|}
$\begin{array}{c}\text { Tablica 5. Količine magnezija u mlinarskim } \\
\text { proizvodima određenih žitarica u sirovom } \\
\text { stanju }\end{array}$ \\
\hline MLINSKI PROIZVOD & $\begin{array}{c}\text { KOLIČINA MAGNEZIJA } \\
\text { (mg / } 100 \text { g) }\end{array}$ \\
\hline Bijeli pšenični kruh & 41 \\
\hline Mekinje od oljuštene pšenice & 611 \\
\hline Ječmeno brašno & 96 \\
\hline Proseno brašno & 119 \\
\hline Raženi kruh & 40 \\
\hline Raženo brašno, oljuštena raž & 32 \\
\hline Raženo brašno, cjelovito zrno & 160 \\
\hline Mekinje od kukuruza & 64 \\
\hline Instantne zobene pahuljice & 112 \\
\hline Brašno od heljde, cjelovito zrno & 251 \\
\hline Izvor: United States Department of Agriculture, Agricultural \\
Research Service, National Nutrient Database for Standard \\
Reference Legacy Release
\end{tabular}

\section{Cilj rada}

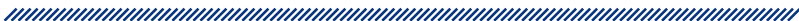

S obzirom na nutritivna svojstva žitarica, osobito mikronutrijenata, cilj je ovoga rada bio utvrditi količinu magnezija u odabranim žitaricama i mlinskim proizvodima te prikazati zdravstvene dobrobiti magnezija. Analizirani su uzorci pšenice i kukuruza te njihovih mlinskih proizvoda (brašna), a analize su provedene provjerenim i međunarodno priznatim analitičkim tehnikama pri- mjerenima za ovu vrstu uzoraka. Nakon obrade uzoraka u mikrovalnoj pećnici, primjenom dušične kiseline, vodikova peroksida i snage mikrovalova, identifikacija i kvantifikacija uzoraka provedena je analiza vezanim sustavom induktivno spregnute plazme i spektrometrije masa (ICP-MS). Nakon obrade dobivenih rezultata procijenjena je važnost uporabe analiziranih žitarica u svakodnevnoj prehrani kao važnog izvora magnezija.

\section{Materijal i metode}

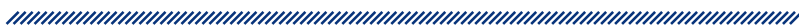

Na Nastavni zavod za javno zdravstvo „Dr. Andrija Štampar” 2017. doneseno je ukupno 28 uzoraka žitarica i mlinskih proizvoda u cilju analize zdravstvene ispravnosti navedenih proizvoda na teške metale i druge parametre. Tijekom tog istraživanja analiza na magnezij nije provedena. Budući da je magnezij vrlo važan mikronutrijent za ljudski organizam i nužno ga je svakodnevno unositi putem hrane, javila se potreba za ispitivanjem dostavljenih uzoraka i na prisutnost magnezija. Cilj istraživanja bio je ispitati koliki postotak magnezija sadrži pojedini proizvod i jesu li te vrijednosti u skladu s dobivenim vrijednostima drugih istraživanja. Tijekom analize sastava navedenih žitarica i mlinskih proizvoda analizirano je sveukupno 28 uzoraka. Od toga je bilo pet uzoraka kukuruza u zrnu, sedam uzoraka pšenice, 11 uzoraka pšeničnog brašna, brašno od integralne heljde bez glutena, zobena kaša, prosena kaša, kaša zobi, ječma i pira te kaša riže, kukuruza i heljde.

Organska se tvar nakon homogeniziranja mokro razgradi koncentriranom dušičnom kiselinom $\left(\mathrm{HNO}_{3}\right)$ i vodikovim peroksidom $\left(\mathrm{H}_{2} \mathrm{O}_{2}\right)$ u uređaju za mikrovalnu razgradnju. $U$ dobivenoj bistroj otopini nakon razrjeđenja mjeri se sadržaj metala i metaloida metodom atomske apsorpcijske spektrometrije (AAS) i induktivno spregnutom plazmom spektrometrije masa (ICP-MS). ${ }^{32,33}$ 


\section{Rezultati}

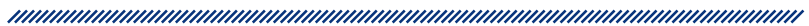

Rezultati dobiveni na temelju istraživanja navedenih žitarica i mlinskih proizvoda prikazani su grafički.

Grafikon 1 prikazuje količine magnezija u sedam različitih uzoraka pšenice. Količina magnezija u uzorcima kreće se u rasponu od 81,92 do 148,45 mg Mg / $100 \mathrm{~g}$ svježe tvari. Znatno veća količina magnezija utvrđena je u uzorku pšenice 5 (148,45 mg Mg / 100 g), dok je najmanja količina magnezija utvrđena u uzorku pšenice 3 (81,92 mg Mg / $100 \mathrm{~g})$.

\begin{tabular}{|c|c|}
\hline \multicolumn{2}{|c|}{$\begin{array}{c}\text { Tablica 6. Količina, raspon i srednja vrijednost } \\
\text { magnezija (mg/kg) }\end{array}$} \\
\hline u uzorcima pšenice \\
\hline 1 & Količina Mg (mg/kg) \\
\hline 2 & 1021 \\
\hline 3 & 1069,8 \\
\hline 4 & 819,2 \\
\hline 5 & 931,5 \\
\hline 6 & 1484,5 \\
\hline 7 & 1056 \\
\hline Raspon vrijednosti Mg & 1024,7 \\
\hline Srednja vrijednost Mg & $819,2-1484,5$ \\
\hline
\end{tabular}

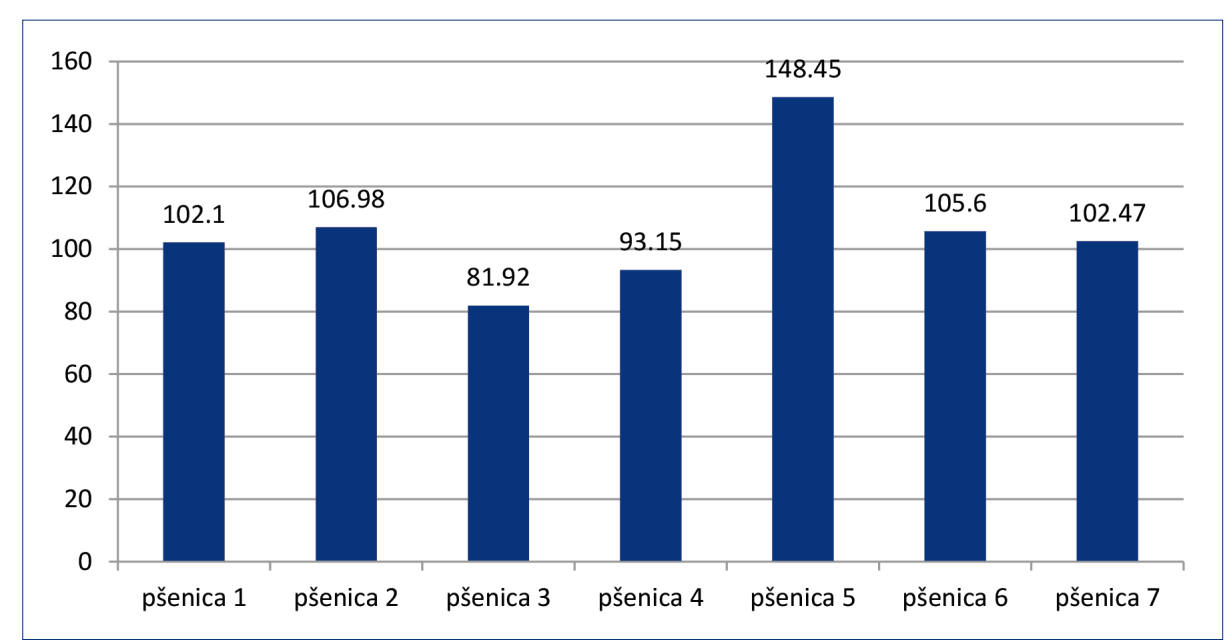

Grafikon 1. Količina magnezija (mg / 100 g uzorka) u sedam različitih uzoraka pšenice

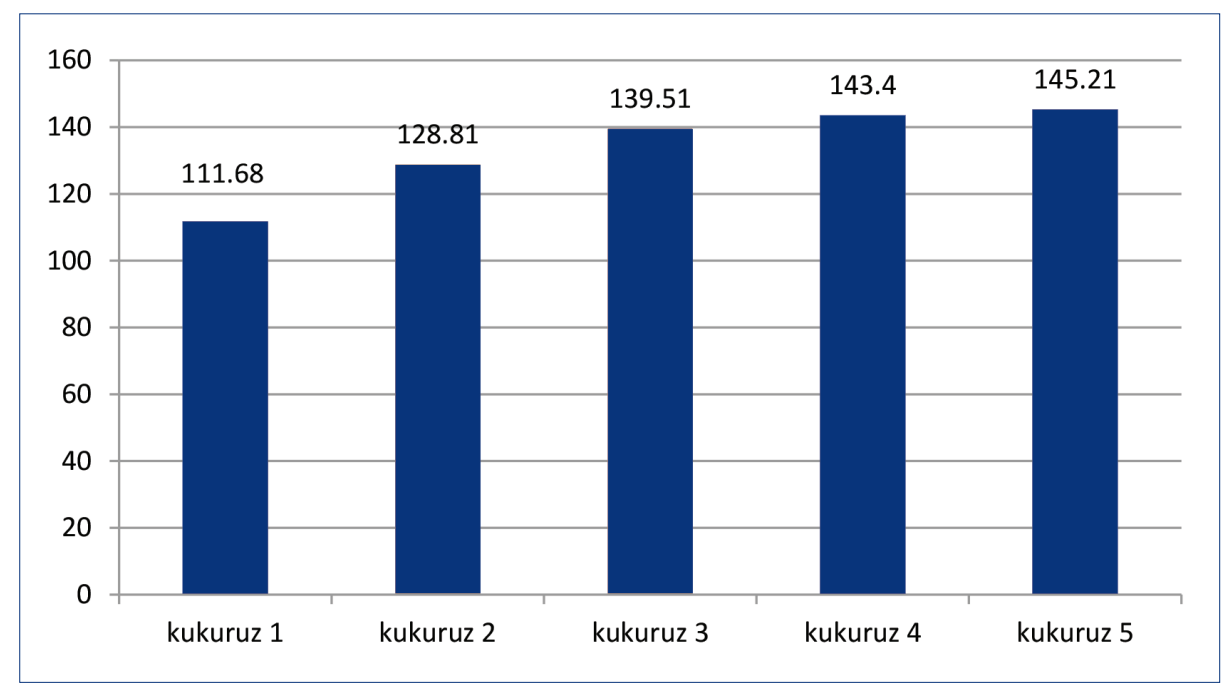

Grafikon 2. Količina magnezija (mg Mg / 100 g uzorka) u uzorcima kukuruza 
Tablica 6 prikazuje količinu magnezija, raspon vrijednosti te srednju vrijednost magnezija $u$ analiziranim uzorcima pšenice u $\mathrm{mg} / \mathrm{kg}$. Srednja vrijednost magnezija analiziranih uzoraka pšenice iznosi $1058,1 \mathrm{mg} / \mathrm{kg}$ odnosno 105,81 mg / 100 g. Raspon vrijednosti magnezija kreće se od 819,2 mg/kg do 1484,5 mg/kg.

Količina magnezija u uzorcima kukuruza prikazana je u grafikonu 2. Kreće se u rasponu od 111,68 do 145,21 mg $\mathrm{Mg} / 100 \mathrm{~g}$ svježe tvari. Najmanja vrijednost utvrđena je u uzorku kukuruza 1 (111,68 mg Mg / 100 g), dok je najveća vrijednost utvrđena u uzorku kukuruza 5 $(145,21 \mathrm{mg} \mathrm{Mg} / 100 \mathrm{~g})$.

\begin{tabular}{|c|c|}
$\begin{array}{c}\text { Tablica 7. Količina, raspon i srednja vrijednost } \\
\text { magnezija (mg/kg) }\end{array}$ \\
\hline ur. uzorcima kukuruza \\
\hline $\mathbf{1}$ & Količina Mg (mg/kg) \\
\hline 2 & 1116,8 \\
\hline $\mathbf{3}$ & 1288,1 \\
\hline $\mathbf{4}$ & 1395,1 \\
\hline $\mathbf{5}$ & 1434,0 \\
\hline Raspon vrijednosti Mg & 1452,1 \\
\hline Srednja vrijednost Mg & $1116,8-1452,1$ \\
\hline
\end{tabular}

Količina, raspon i srednja vrijednost magnezija $(\mathrm{mg} / \mathrm{kg})$ za analizirane uzorke kukuruza u zrnu prikazana je u tablici 7. Raspon vrijednosti magnezija u uzorcima kukuruza u zrnu kreće se od 1116,8 mg/kg do 1452,1 mg/ $\mathrm{kg}$. Srednja vrijednost magnezija u analiziranim uzorcima kukuruza u zrnu iznosi $1337,2 \mathrm{mg} / \mathrm{kg}$ odnosno $133,72 \mathrm{mg} / 100 \mathrm{~g}$.
Grafikon 3 prikazuje količine magnezija u različitim kašama. Analizirani su uzorci prosene kaše, zobene kaše, kaše od zobi, ječma i pira te kaše od riže, kukuruza i heljde. Vrijednosti se kreću u rasponu od 76,77 do $153,61 \mathrm{mg} \mathrm{Mg} / 100 \mathrm{~g}$ svježe tvari. U kaši od riže, kukuruza i heljde utvrđena je najmanja količina magnezija (76,77 mg Mg / 100 g) dok je u prosenoj kaši utvrđena najveća količina (153,61 mg Mg / 100 g).

\begin{tabular}{c|c|}
$\begin{array}{c}\text { Tablica 8. Količina, raspon i srednja vrijednost } \\
\text { magnezija (mg/kg) }\end{array}$ \\
\hline u uzorcima kaše
\end{tabular}

Tablica 8 prikazuje količinu, raspon i srednju vrijednost magnezija $(\mathrm{mg} / \mathrm{kg})$ u analiziranim uzorcima kaše. Raspon vrijednosti magnezija kreće se od $767,7 \mathrm{mg} / \mathrm{kg}$ do $1536,1 \mathrm{mg} / \mathrm{kg}$, dok srednja vrijednost iznosi 1229,8 mg/ kg odnosno 122,98 mg / $100 \mathrm{~g}$.

Količina magnezija u brašnu, pšeničnom i heljdinu, prikazana je u grafikonu 4 i kreće se u rasponu od 23,17 do 226,32 mg Mg / 100 g svježe tvari. Najmanja vrijednost magnezija utvrđena je u pšeničnom brašnu 11 (23,17 mg $\mathrm{Mg} / 100 \mathrm{~g}$ svježe tvari), dok je najveća vrijednost utvrđena u brašnu od integralne heljde bez glutena $(226,32 \mathrm{mg}$ $\mathrm{Mg} / 100 \mathrm{~g}$ svježe tvari). Vrijednosti pšeničnog brašna kreću se u rasponu od 23,17 do $60,41 \mathrm{mg} \mathrm{Mg} \mathrm{/} 100$ g svježe tvari.

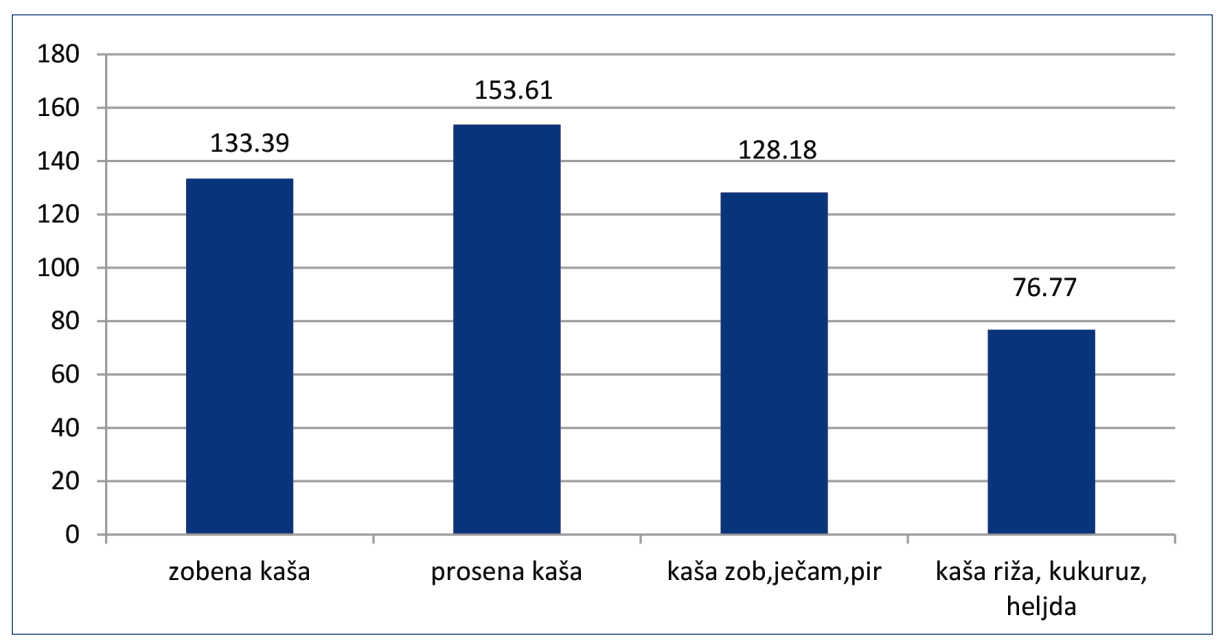

Grafikon 3. Količina magnezija (mg Mg / 100 g uzorka) u uzorcima kaše 
Tablica 9. Količina, raspon i srednja vrijednost magnezija (mg/kg) u uzorcima pšeničnog brašna

\begin{tabular}{|c|c|}
\hline Br. uzorka & Količina $\mathrm{Mg}(\mathrm{mg} / \mathrm{kg})$ \\
\hline $\mathbf{1}$ & 299,3 \\
\hline $\mathbf{2}$ & 316,5 \\
\hline $\mathbf{3}$ & 321,3 \\
\hline $\mathbf{5}$ & 337,8 \\
\hline $\mathbf{6}$ & 282,7 \\
\hline $\mathbf{7}$ & 380,6 \\
\hline $\mathbf{8}$ & 316,3 \\
\hline $\mathbf{9}$ & 381,7 \\
\hline 10 & 604,1 \\
\hline 11 & 329,3 \\
\hline Raspon vrijednosti Mg & 231,7 \\
\hline Srednja vrijednost Mg & $231,7-604,1$ \\
\hline
\end{tabular}

U tablici 9 prikazana je količina, raspon te srednja vrijednost magnezija $(\mathrm{mg} / \mathrm{kg})$ u 11 analiziranih uzoraka pšeničnog brašna. Raspon vrijednosti magnezija kreće se od $231,7 \mathrm{mg} / \mathrm{kg}$ do $604,1 \mathrm{mg} / \mathrm{kg}$. Srednja vrijednost iznosi 345,6 mg/kg odnosno 34,56 mg / $100 \mathrm{~g}$.

Grafikon 5 prikazuje prosječne vrijednosti za sve analizirane uzorke iz istraživanja. Najveća prosječna vri- jednost magnezija utvrđena je u uzorcima kukuruza u zrnu (133,72 mg / 100 g), dok je najmanja vrijednost magnezija utvrđena u uzorcima pšeničnog brašna (34,56 mg / $100 \mathrm{~g})$. U analiziranim uzorcima pšenice utvrđena je vrijednost magnezija od 105,81 mg / $100 \mathrm{~g}$, dok je u analiziranim uzorcima kaše utvrđena vrijednost magnezija od 122,99 mg / $100 \mathrm{~g}$.

\begin{tabular}{|c|c|}
\hline $\begin{array}{c}\text { Tablica 10. Prosječne količine magnezija } \\
\text { (mg/kg) u analiziranim uzorcima }\end{array}$ \\
\hline Vrsta uzorka & Količina Mg $(\mathrm{mg} / \mathrm{kg})$ \\
\hline uzorci pšenice & 1058,1 \\
\hline uzorci kukuruza & 1337,2 \\
\hline uzorci kaše & 1229,9 \\
\hline uzorci pšeničnog brašna & 345,6 \\
\hline
\end{tabular}

Tablica 10. Prikazuje prosječne vrijednosti magnezija $(\mathrm{mg} / \mathrm{kg})$ po skupinama za analizirane uzorke. Uzorci kukuruza u zrnu imaju najveću vrijednost magnezija $(1337,2 \mathrm{mg} / \mathrm{kg})$, dok uzorci pšeničnog brašna imaju najmanju vrijednost magnezija $(345,6 \mathrm{mg} / \mathrm{kg})$ među analiziranim skupinama uzoraka. U uzorcima pšenice utvrđena je prosječna količina magnezija od 1058,1 mg/kg. Prosječna količina magnezija u uzorcima kaše iznosila je $1229,9 \mathrm{mg} / \mathrm{kg}$.

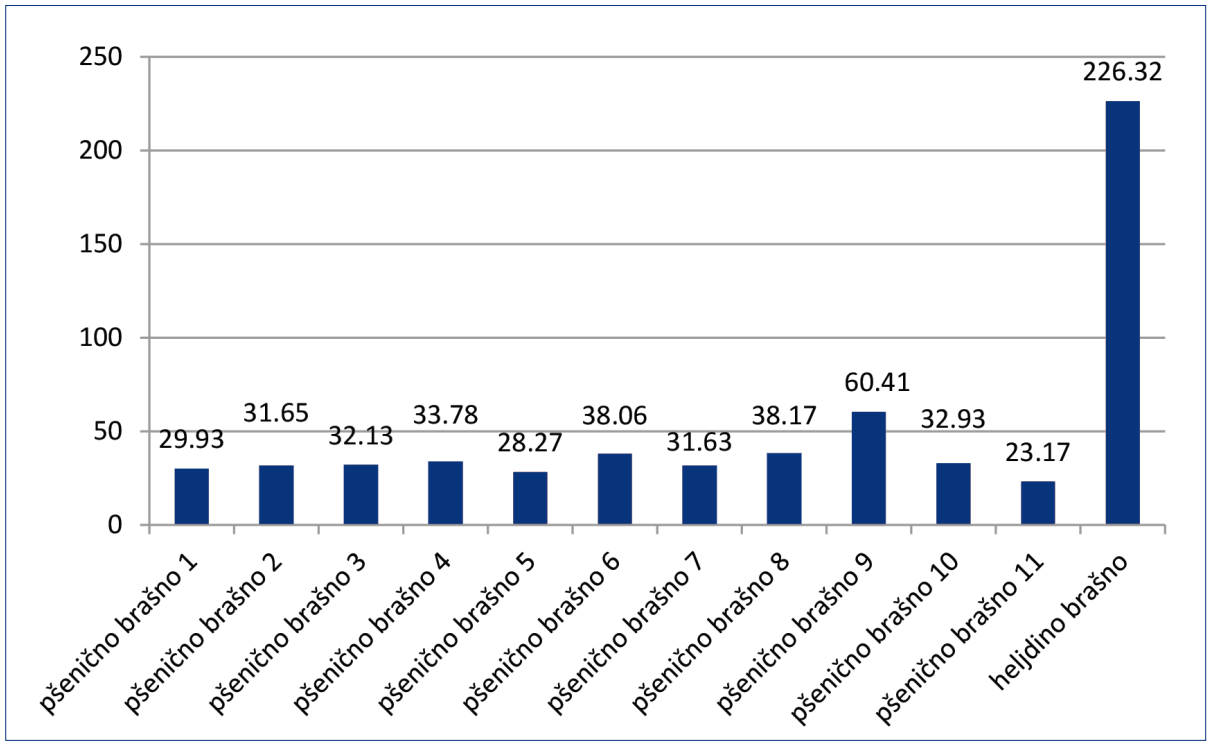

Grafikon 4. Količina magnezija (mg Mg / 100 g uzorka) u pšeničnom i heljdinu brašnu 


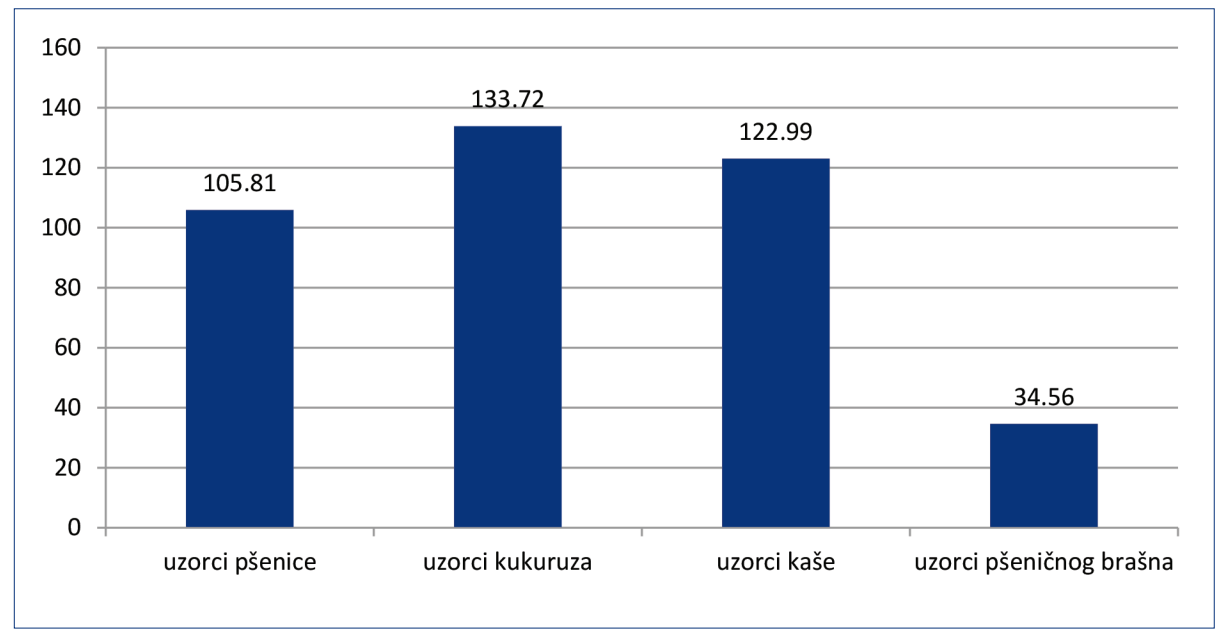

Grafikon 5. Prosječne vrijednosti magnezija u analiziranim uzorcima po skupinama analiziranih uzoraka (mg / $100 \mathrm{~g}$ )

\section{Rasprava}

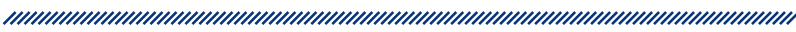

Prema rezultatima ovog istraživanja, utvrđeno je da se količina magnezija u pšenici kreće u rasponu od 81,92 do 148,45 mg Mg / 100 g svježe tvari (od 819,2 do $1484,5 \mathrm{mg} / \mathrm{kg}$ ) (grafikon 1). Norton (2012) na temelju istraživanja provedenog na 130 uzoraka pšenice iz jugoistočne Australije navodi da prosječna vrijednost količine magnezija u pšenici iznosi $1281 \mathrm{mg} / \mathrm{kg}$ odnosno $128,1 \mathrm{mg} / 100 \mathrm{~g} .{ }^{28}$ Količina magnezija u tim uzorcima pšenice utvrđena je metodom ICP-OES. International Plant Nutrition Institute (IPNI) ${ }^{35}$ proveo je istraživanje u različitim državama i rezultati količine magnezija u pšenici prikazani su po državama; Kanada 1407,3 mg/kg (140,73 mg / 100 g), Rusija 873 mg/kg (87,3 mg / 100 g), Kina 1176 mg/kg (117,6 mg / 100 g), SAD 1633,3 mg/kg (163,33 mg / $100 \mathrm{~g})$ te Indija s vrijednošću od 978,0 mg/ kg (97,8 mg / 100 g). Uspoređujući dobivene rezultate prethodno spomenutih istraživanja i rezultate ovog istraživanja može se zaključiti da uzorak pšenice 3 (grafikon 1), koji ima najmanju količinu magnezija u sastavu od svih uzoraka na kojima je provedena ova analiza, ima manju vrijednost od svih dobivenih vrijednosti drugim istraživanjima s $819,2 \mathrm{mg} / \mathrm{kg}$ odnosno $81,92 \mathrm{mg} / 100 \mathrm{~g}$. Vrijednost najveće količine magnezija u pšenici dobivena ovim istraživanjem iznosi 1484,5 mg/kg (grafikon 1). Prosječna vrijednost količine magnezija u Hrvatskoj iznosi 1058,1 mg/kg odnosno 105,81 mg / 100 g (grafikon 5), prema čemu možemo zaključiti da se ta vrijednost nalazi unutar intervala prosječnih vrijednosti osta- lih država, ali je ipak u donjoj granici svih tih vrijednosti. Vidljivo je da se prosječne vrijednosti znatno razlikuju od države do države. Razlog tomu može biti druga sorta pšenice, različita klima i različit reljef na kojem se pšenica uzgaja. Također, različita aplikacija gnojiva, ali i sama priprema uzorka za analizu odnosno digestija te postupak provođenja cijelog istraživanja mogu biti razlozi tako velike razlike u dobivenim prosječnim vrijednostima različitih država.

Tijekom ovog istraživanja provedena je i analiza na pet uzoraka kukuruza u zrnu. Raspon dobivenih vrijednosti količine magnezija u uzorcima kreće se od 111,68 do $145,21 \mathrm{mg} / 100 \mathrm{~g}$ svježe tvari (od 1116,8 do $1452,1 \mathrm{mg} \mathrm{Mg} / \mathrm{kg}$ ), dok srednja vrijednost magnezija iznosi 133,72 mg / 100 g odnosno 1337,2 mg/kg. Codling i sur. (2007) 36 u svojem istraživanju navode količine magnezija u rasponu od 909 do $1017 \mathrm{mg} / \mathrm{kg}$ utvrđene metodom ICP-AES nakon digestije s $3 \mathrm{ml} \mathrm{HNO}$ i $10 \mathrm{ml} 3$ $\mathrm{M} \mathrm{HCl}$. Istraživanje koje su proveli Ferreira i sur. (2012) ${ }^{37}$ atomskom apsorpcijskom spektrometrijom (AAS) nakon suhe digestije pokazalo je rezultate za količinu magnezija u rasponu od 1320 do $1710 \mathrm{mg} / \mathrm{kg}$ (od 132 do $171 \mathrm{mg} / 100 \mathrm{~g}$ ) za 10 različitih kultivara kukuruza. USDA $(2018)^{38}$ navodi količinu od $127 \mathrm{mg} / 100$ g. Prema tome se može zaključiti da su i rezultati ovog istraživanja u intervalu vrijednosti svih ostalih s manjim ili većim odstupanjima, što opet možemo objasniti utjecajem različitih faktora na sve navedene uzorke.

Dobivene vrijednosti količine magnezija u 11 analiziranih uzoraka brašna tijekom ovog istraživanja kreću se u rasponu od 23,17 do 60,41 mg/ $100 \mathrm{~g}(231,7$ do $604,1 \mathrm{mg} /$ 
kg). Srednja vrijednost za analizirane uzorke pšeničnog brašna iznosi 34,56 mg / $100 \mathrm{~g}$ (grafikon 5) odnosno $345,6 \mathrm{mg} / \mathrm{kg}$ (tablica 10). Raquele i sur. (2013) ${ }^{39}$ metodom ICP (ICAP 6300 spektrofotometar) utvrdili su količinu magnezija od 226,7 $\pm 10,54$ i 226,4 $\pm 6,632 \mathrm{mg} / \mathrm{kg}$, dok je istraživanje koje su proveli Peterson i sur. $(1983)^{40}$ pokazalo znatno veće vrijednosti količine magnezija u pšeničnom brašnu i nalaze se u rasponu od 757 do $906 \mathrm{mg} / \mathrm{kg}$ odnosno od 75,7 do 90,6 mg / 100 g. Vidljivo je da su vrijednosti rezultata dobivenih ovim istraživanjem slični kao i oni dobiveni istraživanjem koje su proveli Raquele i sur. (2013), dok su vrijednosti koje su dobili Peterson i sur. (1983) znatno veće. Razlog tomu može biti taj što je količina magnezija kod tog istraživanja utvrđena metodom EDXRF (engl. energy-dispersive $X$-ray fluorescence spectrometry) za koju je potrebno samo usitnjavanje i peletiranje uzorka te se tako izbjegava potencijalni gubitak uzorka u ostalim postupcima. ${ }^{40}$

Vrijednosti magnezija u uzorcima kaše ovog istraživanja kreću se u rasponu od 76,77 do 153,61 mg / 100 g odnosno od 767,7 do $1536,1 \mathrm{mg} / \mathrm{kg}$. Prosječna vrijednost magnezija za analizirane uzorke kaše iznosi 122,98 mg/ $\mathrm{kg}$. McKevith (2004)1 navodi kao rezultate svojeg istraživanja vrijednosti od $110 \mathrm{mg} / 100 \mathrm{~g}$ u zobenoj kaši, a ovim istraživanjem dobivena je vrijednost $133,39 \mathrm{mg}$ Mg / $100 \mathrm{~g}$ za zobenu kašu. Može se pretpostaviti da je razlika u vrijednosti prisutna zbog druge metode rada te druge sorte zobi. Podaci za preostala tri uzorka kaše nisu pronađeni u drugim istraživanjima. Prema ovom istraživanju, najveću količinu magnezija sadrži prosena kaša $(153,61 \mathrm{mg} / 100 \mathrm{~g})$, dok je najmanja vrijednost utvrđena u uzorku kaše od riže, kukuruza i heljde (76,77 mg / 100 g). Također je u kaši od zobi, ječma i pira utvrđena manja vrijednost u odnosu na zobenu i prosenu kašu (128,13 mg / 100 g). Može se pretpostaviti da je to zbog različitog omjera žitarica u kaši. Ako se u omjer stave dobiveni rezultati količine magnezija u proizvodima iz ovog istraživanja i preporučeni dnevni unos magnezija Uredbe Europskog parlamenta i vijeća o informiranju potrošača o hrani (1169/2011) ${ }^{41}$ od 375 mg/ dan, dobiva se postotak podmirenja dnevnih potreba za magnezijem konzumiranjem spomenutih proizvoda. Prema tome, konzumacijom $100 \mathrm{~g}$ ispitivanih uzoraka pšenice zadovoljava se od 22 do $39 \%$ dnevnih potreba za magnezijem. Konzumacijom $100 \mathrm{~g}$ ispitivanih uzoraka kukuruza zadovoljava se od 30 do $39 \%$ preporučenog dnevnog unosa, a konzumacijom $100 \mathrm{~g}$ pšeničnog brašna od 6,2 do $16 \%$. Konzumacijom $100 \mathrm{~g}$ brašna od integralne heljde bez glutena zadovoljava se čak $60 \%$ dnevnih potreba za magnezijem.

\section{Zaključak}

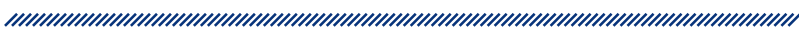

$\mathrm{U}$ istraživanju su utvrđene količine magnezija u sedam uzoraka pšenice, pet uzoraka kukuruza u zrnu, 11 uzoraka pšeničnog brašna, brašnu od integralne heljde bez glutena, zobenoj kaši, prosenoj kaši, kaši zobi, ječma i pira te kaši riže, kukuruza i heljde. Svi su uzorci osim uzoraka kaše s područja Republike Hrvatske.

Na osnovi provedenog istraživanja i dobivenih rezultata možemo zaključiti:

1. U analiziranim uzorcima pšenice količine magnezija kretale su se od 81,92 do 148,45 mg / $100 \mathrm{~g}$, a srednja vrijednost iznosila je 105,81 mg / $100 \mathrm{~g}$.

2. U uzorcima kukuruza količine dobivenog magnezija kretale su se od 111,68 do 145,21 mg / 100 g, dok je srednja vrijednost $u$ analiziranim uzorcima iznosila 133,72 mg / $100 \mathrm{~g}$.

3. Količina magnezija u uzorcima pšeničnog brašna kretala se od 23,17 do $60,41 \mathrm{mg} / 100 \mathrm{~g}$, dok je srednja vrijednost magnezija $u$ analiziranim uzorcima iznosila $34,56 \mathrm{mg} / 100 \mathrm{~g}$.

4. Količina magnezija u brašnu od integralne heljde bez glutena iznosila je 226,32 mg / $100 \mathrm{~g}$.

5. Količina magnezija u analiziranim uzorcima kaše kretala se od 76,77 do 153,61 mg / 100 g. Prosječna vrijednost magnezija u uzorcima kaše iznosila je $122,98 \mathrm{mg} / 100 \mathrm{~g}$.

6. Konzumacijom $100 \mathrm{~g}$ pšenice iz ovog istraživanja može se podmiriti od 22 do $39 \%$ dnevnih potreba za magnezijem. Konzumacijom $100 \mathrm{~g}$ kukuruza iz ovog istraživanja može se podmiriti od 30 do $39 \%$ dnevnih potreba za magnezijem, dok se konzumacijom $100 \mathrm{~g}$ pšeničnog brašna može podmiriti 6,2 do $16 \%$ dnevnih potreba za magnezijem. Konzumacijom $100 \mathrm{~g}$ brašna od integralne heljde bez glutena se može podmiriti $60 \%$ dnevnih potreba za magnezijem.

7. Prema svemu navedenom može se zaključiti da su žitarice i mlinski proizvodi dobar izvor minerala magnezija. Njihovom konzumacijom unosimo zadovoljavajući postotak potrebnog dnevnog unosa magnezija, a osobito kada je riječ o proizvodima na bazi heljde.

\section{Zahvala}

Rad je izrađen kao dio projekata Centra za sigurnost i kvalitetu hrane (K.K. 01.1.1.02.0004), financiranom od Europskog regionalnog fonda za razvoj. 


\section{Referencije}

1. McKevith B. Nutritional aspects of cereals. London: British Nutrition Foundation; 2004. 29: 111-142.

2. Ministarstvo poljoprivrede. Pravilnik o žitaricama i proizvodima od žitarica. Narodne novine 81/2016: 2-3.

3. Hrsto D. Mlinarska industrija Republike Hrvatske. Pregledni rad. Sociologija sela; 1993. 31: 115-123.

4. U.S. Department of Health \& Human Services. Magnesium - Fact Sheet for Health Professionals. National Institutes of Health, Office of dietary supplements; 2018. Dostupno na: https://ods.od.nih.gov/factsheets/Magnesium-HealthProfessional/

5. Romani AM. Cellular magnesium homeostasis. U.S. National Library of Medicine, Arch Biochem Biophys; 2011; 512 (1): 1-23.

6. Swaminathan R. Magnesium Metabolism and its Disorders. Clin Biochem Rev. U.S. National Library of Medicine; 2003; 24 (2): 47-66.

7. Čepelak I, Dodig S, Čulić O. Magnesium - more than a common cation. Review article. Zagreb: Faculty of Pharmacy and Biochemistry; 2013; 47-68.

8. Katić M. Magnezij: Popaj je dobro izabrao špinat. U: Šatalić Z., ur. 100 (i pokoja više) crtica iz znanosti o prehrani. Zagreb: Hrvatsko društvo prehrambenih tehnologa, biotehnologa i nutricionista; 2013; 25-26.

9. Costello R, Wallace T, Rosanoff A. Magnesium. Review article. U.S. National Library of Medicine; 2016; 7 (1): 199-201. Dostupno na: https://doi.org/10.3945/ an.115.008524 (pristupljeno 21.8.2018.).

10. Belitz HD, Grosch W, Schieberle P. Food Chemistry. 4th revised and extended Edition. München: Springer Verlag Berlin Heidelberg; 2009.

11. Gröber U, Schmidt J, Kisters K. Magnesium in Prevention and Therapy. U.S. National Library of Medicine, Journal list: Nutrients. 2015; 7 (9): 8199-8226.

12. Institute of Medicine (IOM). Food and Nutri Board. Dietary Reference Intakes: Calcium, Phosphorus, Magnesium, Vitamin D and Fluoride. Washington, DC: National Academy Press; 1997.

13. Larsson S, Wolk A. Magnesium intake and risk of type 2 diabetes: A meta-analysis. 2007; 262 (2): 208214. Dostupno na: https://www.ncbi.nlm.nih.gov/ pubmed/17645588 (pristupljeno 21.8.2018.).

14. Jee S, Miller E, Guallar E, Singh V, Appel L, Klag M. The effect of magnesium supplementation on blood pressu-

re: A meta-analysis of randomized clinical trials. 2002; 15(8): 691-696. Dostupno na: https://www.ncbi.nlm.nih. gov/pubmed/12160191 (pristupljeno 22.8.2018.).

15. Kisters K. What is the correct magnesium supplement? 2013; 26: 41-42., Dostupno na: https://www.ncbi.nlm. nih.gov/pubmed/23708889 (pristupljeno 22.8.2018.).

16. Gröber U. Micronutrients: Metabolic Tuning-PreventionTherapy / Magnesium. Stuttgart, Germany: MedPharm Scientific Publishers; 2009.

17. Moshfegh A, Goldman J, Ahuja J, Rhodes D, LaComb R. What We Eat in America, NHANES 2005-2006: Usual Nutrient Intakes from Food and Water Compared to 1997 Dietary Reference Intakes for Vitamin D, Calcium, Phosphorus, and Magnesium; 2009.

18. Jonnalagdda S, Harnack L, Liu R, McKeown N, Seal C, Liu S, Faheg G. Putting the Whole Grain Puzzle Together: Health Benefits Associated with Whole Grains - Summary of American Society for Nutrition 2010 Satellite Symposium; 2011; 141 (5): 1011S-1022S. Dostupno na: https:// www.ncbi.nlm.nih.gov/pubmed/21451131 (pristupljeno 22.8.2018.).

19. Pšenica (Triticum ap. L.). Poljoprivredni fakultet Osijek; 2004., dostupno na: http://www.obz.hr/vanjski/CD_ AGBASE2/HTM/psenica.htm (pristupljeno 22.8.2018.).

20. Self nutrition data. Dostupno na: https://nutritiondata. self.com/ (pristupljeno 23.8.2018.).

21. Saleh ASM, Zhang Q, Chen J, Shen Q. Millet Grains: Nutritional Quality, Processing, and Potential Health Benefits. Comprehensive reviews in Food Science and Food Safety. 2013; 12 (3): 281-295. Dostupno na: https://doi. org/10.1111/1541-4337.12012 (pristupljeno 23.8.2018.).

22. Johansson D, Lee I, Riserus U, Langton M, Landberg R. Effects of Unfermented and Fermented Whole Grain Rye Crisp Breads Served as Part of a Standardized Breakfast, on Appetite and Postprandial Glucose and Insulin Responses: A Randomized Cross-over Trial Plos One. 2015; 10 (3): 0122241. Dostupno na: https://doi.org/10.1371/ journal.pone.0122241 (pristupljeno 23.8.2018).

23. Sterna V. Oat grain composition and its nutrition benefice. Agriculture and Agricultural Science Procedia. 2016; 8: 252-256. Dostupno na: https://doi.org/10.1016/j.aaspro.2016.02.100 (pristupljeno 23.8.2018.).

24. Arnarson A. Rice 101: Nutrition facts and health effects. Medical News Today. 2017. Dostupno na: https://www. medicalnewstoday.com/articles/318699.php (pristupljeno 23.8.2018.).

25. Liu S, Stampfer M, Hu F, Giovannucci E, Rimm E, Manson $J$, et al. Whole-grain consumption and risk of coronary heart disease: results from the Nurses' Health Study. PubMedorg. 1999; 70 (3): 412-419. Dostupno na: https:// www.ncbi.nlm.nih.gov/pubmed/10479204 (pristupljeno 24.8.2018.).

26. Wang $\mathrm{H}$, Nussbaum-Wagler T, Li B, Zhao Q, Vigouroux $\mathrm{Y}$, Fuller $\mathrm{M}$ et al. The origin of the naked grains of maize. Nature. 2005; 436 (7051): 714-719. Dostupno na: http://dx.doi.org/10.1038\%2Fnature03863 (pristupljeno 
24.8.2018.).

27. The Editors of Encyclopaedia Britannica. Corn. Encyclopaedia Britannica. 2018. Dostupno na: https://www.britannica.com/plant/corn-plant (pristupljeno 24.8.2018.)

28. Ware M. Health benefits of quinoa. Medical News Today. 2018. Dostupno na: https://www.medicalnewstoday. com/articles/274745.php (pristupljeno 24.8.2018.).

29. Benković E, Kreft S. Fagopyrins and Protofagopyrins: Detection, Analysis, and Potential Phototoxicity in Buckwheat. Journal of agricultural and food chemistry. 2015; 63 (24): 5715-5724. Dostupno na: https://doi. org/10.1021/acs.jafc.5b01163 (pristupljeno 24.8.2018.).

30. Giménez-Bastida JA, Zielinski H. Buckwheat as a Functional Food and Its Effects on Health. Journal of agricultural and food chemistry 2015; 63 (36): 7896-7913. Dostupno na: https://pubs.acs.org/doi/abs/10.1021/acs. jafc.5b02498 (pristupljeno 25.8.2018.).

31. Rangelov S. Prehrambena tehnologija - Mlinarski proizvodi. 2014. Dostupno na: http://prehrambenatehnologija.blogspot.com/2014/11/mlinarski-proizvodi.html (pristupljeno 28.8.2018.).

32. Skoog DA, Holler FJ, Crouch SR. Principles of Instrumental Analysis. Sixth Edition. U.S.A.: Thomson Brooks/Cole; 2007.

33. Thomas R. Practical Guide to ICP-MS. Scientific Solutions. Meryland, U.S.A.: Marcel Dekker, Inc.; 2004.
34. Norton R. Wheat grain nutrient concentrations for southeasten Australia. International Plant Nutrition Institute (IPNI). 2012; 17: 9.

35. Jensen T. Wheat Grin Nutrient Content. International Plant Nutrition Institute 2012; 30: 1-4.

36. Codling EE, Mulchi CL, Chaney RI. Grain Yield and Mineral Element Composition of Maize Grown on High Phosphorus Soils Amended with Water Treatment Residual. Journal of Plant Nutrition. 2007; 30: 225-240. Dostupno na: https://doi.org/10.1080/01904160601117937 (pristupljeno 5.10.2018.).

37. Ferreira CF, Motta ACV, Prior SA, Reissman CB, dos Santos NZ, Gabardo J. Influence of Corn (Zea mays L.) Cultivar Development on Grain Nutrient Concentration. International Journal of Agronomy. 2012; 7: 1-7. Dostupno na: http:// dx.doi.org/10.1155/2012/842582 (pristupljeno 5.10.2018.).

38. U.S. Department of Agriculture (USDA). Dostupno na: https://www.usda.gov/ (pristupljeno 5.10.2018.).

39. Tejera RL, Luis G, Weller LD, Caballero JM, Gutiérrez AJ, Rubio C, Hardisson A. Metals in wheat flour; comparative study and safety control. Nutricion Hospitalaria 2013; 28 (2): 506-513.

40. Peterson CJ, Johanson VA, Mattern PJ. Evaluation of Variation in Mineral Element Concentrations in Wheat Flour and Bran of Different Cultivars. Cereal Chem. 1983; 60 (6): 450-455.

41. Uredba (EU) br. 1169/2011 Europskog parlamenta i Vije- 


\section{CEREALS AND MILLED PRODUCTS AS A GOOD SOURCE OF MAGNESIUM IN EVERYDAY DIET}

1 Danijel Brkić

1,2 Jasna Bošnir

1 Andrea Jajetić

1 Ivana Prskalo

1 Jasenka Šabarić

1 Željka Kuharić

1 Željka Pavlek

3 Marijan Benić

2 Aleksandar Racz

1 Andrija Stampar Teaching Institute of Public Health, Zagreb, Mirogojska 16

2 University of Applied Health Sciences, Zagreb, Mlinarska 38

3 Sanatio d.o.o. Bolnička cesta 34 c

\section{Summary}

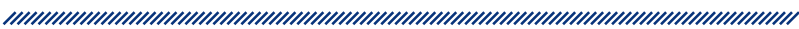

Cereals represent the most prevailing and important culture for human consumption. They are also important as a raw material in the food industry and form the basis of the food pyramid. Milled products also represent basic food products. The main milled products are groats, semolina and flour. Magnesium is a mineral that is an extremely important element in the human body. It ranks fourth in the representation of cations in the body and is the second most common in cells. It plays an important role for the catalytic activity of more than 300 enzymes in the enzymatic systems. It is most important for proper heart function and as a regulator of phosphorus and calcium in the bones. The aim of this paper is to determine the amount of magnesium in selected cereals and milled products and to present the health benefits of magnesium. A total of twenty-eight samples were analysed during the analysis of the composition of cereals and milled products. Of these, there were 5 samples of corn beans, 7 wheat samples, 11 samples of wheat flour, gluten-free whole buckwheat flour, oatmeal, millet porridge, porridge oats, barley and spelt, and rice, corn and buckwheat mash. The analysis was carried out at the Andrija Stampar Teaching Institute of Public Health. After microwave digestion with nitrate acid and hydrogen peroxide, magnesium was determined by inductively coupled plasma with mass spectrometry (ICP-MS). The amounts of magnesium in cereals ranged from $81.92 \mathrm{mg} / 100 \mathrm{~g}$ to $145.21 \mathrm{mg} / 100 \mathrm{~g}$ for wheat, and from $111.68 \mathrm{mg} / 100 \mathrm{~g}$ to $145.21 \mathrm{mg} / 100$ $\mathrm{g}$ for corn. The average magnesium value was 105.81 $\mathrm{mg} / 100 \mathrm{~g}$ for wheat samples and $133.72 \mathrm{mg} / 100 \mathrm{~g}$ for grain corn samples. The amount of magnesium found in wheat flour ranged from $23.17 \mathrm{mg} / 100 \mathrm{~g}$ to 60.41 $\mathrm{mg} / 100 \mathrm{~g}$, while the mean magnesium value was 34.56 $\mathrm{mg} / 100 \mathrm{~g}$. The amount of magnesium in the flour from gluten-free wholegrain buckwheat was $226.32 \mathrm{mg} / 100$ g. The determined amount of magnesium in oatmeal, millet porridge, porridge oats, barley and spelt and porridges of rice, corn and buckwheat ranged from 76.77 $\mathrm{mg} / 100 \mathrm{~g}$ to $153.61 \mathrm{mg} / 100 \mathrm{~g}$. The mean magnesium value for porridge samples was $122.98 \mathrm{mg} / 100 \mathrm{~g}$.

Keywords: mineral, daily need, microelement, magnesium 